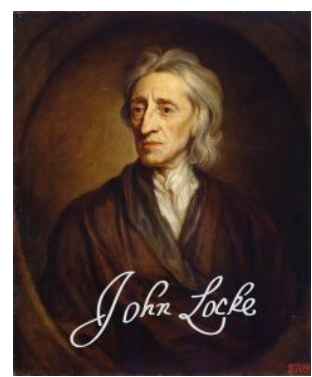

LOCKE STUDIES

Vol. 17

https://doi.org/10.5206/ls.2017.861 | ISSN: 2561-925X

Originally published: 2017

Published online: 01 JANUARY 2019

(c) Locke Studies, 2017

\title{
Locke's Orthography and the Dating of his Writings
}

\author{
J.R. MILTON (LONDON)
}

Recommended citation:

Milton, J.R. "Locke's Orthography and the Dating of his Writings." Locke Studies 17 (2017): 39-47.

https://doi.org/10.5206/ls.2017.861.

For more information about this article:

see this article's webpage.

Locke Studies is published by The John Locke Society.

This is an open access article published under the terms of the Creative Commons AttributionNonCommercial-ShareAlike 4.0 International license, which permits use, distribution and reproduction in any medium, provided the original work is properly cited and shared under the original license. 


\title{
LOCKE'S ORTHOGRAPHY AND THE DATING OF HIS WRITINGS
}

\author{
J. R. MILTON
}

\section{\$1. Locke's spelling}

Anyone reading Locke's works, especially those edited from manuscript, in an unmodernised edition can hardly avoid noticing that his preferred spellings are by no means always those used in present-day English. Something which has been less often noticed is that in several cases his habits changed as he became older, an old-fashioned spelling becoming replaced by a more modern one. The account below focuses on one case of this, and its possible use in estimating the dates of writing - or revisionof several of Locke's writings.

In modern English there is a clear distinction between the word then, used as an adverb ('he was then in London') or-less frequently - as an adjective ('the then Prime Minister'), and the word than, used as a subordinating conjunction ('faster than light'). In the seventeenth century matters were less straightforward: than was rarely if ever used where we would now write then, but the converse was very frequent. A vivid example is provided by the speech of the Fool in Act I, scene 4 of King Lear:
Marke it Nuncle;
Have more then thou showest,
Speake lesse then thou knowest,
Lend lesse then thou owest,
Ride more then thou goest,
Learne more then thou trowest,
Set lesse then thou throwest...

The two words were originally the same, though the spelling of each form in Old English and Middle English varied greatly. According to the Oxford English Dictionary, when the adverb 
came regularly to be spelt then, as it did from the 15 th century onwards, 'there was a strong tendency to spell the conjunction in the same way, which during the 16th century nearly triumphed; but in the 17th century the tide turned, and by 1700 or a little later the conjunction was differentiated from the adverb as than.' ${ }^{1}$

This change is clearly visible in Locke's manuscripts. In his early years he seems to have used then exclusively: in two of the longest works that he composed in the 1660s, the First Tract on Government (1660) and the Essay concerning Toleration (1667), the word than never occurs. ${ }^{2}$ Towards the end of his life, by contrast, than had become the normal form, and then (with the sense than) very much rarer. In The Conduct of the Understanding (1697), which is the longest work from the last decade of Locke's life to have survived in a manuscript in his own hand, than occurs 85 times, then only 5 times. $^{3}$ (In these figures and those which follow the very frequent occurrences of then as an adverb are not included.) In two rather earlier works for which the only known manuscript is a scribal copy the same pattern of usage is apparent: in the Remarks upon some of $\mathrm{Mr}$ Norris's Books (1693), than occurs 14 times, then only once; in the Examination of Malebranche (also 1693), than occurs 48 times, then only 3 times. $^{4}$ In the longest the manuscripts in Locke's hand from the years 1689-92, 'A Call to the Nation for Unity' (1690), ${ }^{5}$ then is not found, while than appears 4 times.

${ }^{1}$ OED, s.v. than, contractions expanded.

${ }^{2}$ I am very grateful to Jacqueline Rose for providing me with an electronic text of the First Tract.

${ }^{3}$ These calculations are made from the manuscript in Bodleian Library [Bodl.], MS Locke e. 1; in the first printed version in The Posthumous Works of Mr. John Locke (London, 1706) only one of these five survives, in the first sentence of $\S 38$.

${ }^{4}$ Bodl., MS Locke d. 3, pp. 1-86 (Malebranche), 89-109 (Norris). I am very grateful to Jonathan Walmsley for providing me with electronic texts of these, and of the Conduct.

${ }^{5}$ Bodl., MS Locke e. 18, printed in James Farr and Clayton Roberts, 'John Locke on the Glorious Revolution: A Rediscovered Document', Historical Journal 28 (1985): 385-98. 
Only a few years earlier the pattern had been very different. In the longest piece of writing to survive from the 1680s, Draft C of the Essay (1685), ${ }^{6}$ the word than never occurs. (This manuscript is mostly in the hand of Locke's manservant, Sylvester Brounower, but as far as can be judged, Brounower followed Locke's orthography quite closely.) Than never occurs in another manuscript in Brounower's hand, the Epitome of the Essay $(c .1685),{ }^{7}$ and also does not occur in two shorter works from around this time where the manuscript is mostly or entirely in Locke's hand: the English Draft of the Adversariorum Methodus (1685), and Of Ethick in General (c.1686-7). ${ }^{8}$

The evidence set out in the preceding paragraphs suggests that a change of usage took place at some time in the late 1680s. This is also the picture that emerges from an examination of both Locke's journal and his correspondence.

Than was not used at all in the volumes of Locke's journal that cover the four years in England after his return from France in 1679. In the volumes that cover his exile in the Netherlands (1683-9) the first entry in which the word can be found was made on 27 October 1688 (where it occurs three times), and this was followed by four more instances in the same year, one on 8 November, and three on 13 December. The last use of then as a conjunction was on 12 December 1688 , and it occurs only twice more with this meaning in the final volume of the journal, on 16 September 1692 and 27 August 1700.

In examining Locke's correspondence, it is safest to use as evidence only those letters where Locke's autograph survives, and not any for which we have to depend on a transcription made by a later editor, such as Benjamin Rand. The word than does not

${ }^{6}$ Pierpont Morgan Library, New York, MA 998.

${ }^{7}$ Bodl., MS Locke c. 28, fos 52-83.

${ }^{8}$ British Library, Add. MS 28728, fos 54-63; Bodl., MS Locke c. 28, fos 145-52. 'Adversariorum Methodus' was Locke's own title for his description of how to make a commonplace book, subsequently published as the 'Méthode nouvelle de dresser des recueuils' in the Bibliothèque universelle et historique, 2 (1686): 315-40. 
appear to occur in any letter written before the late $1680 \mathrm{~s} .{ }^{9}$ The first occurrence of than that I have noticed is in a letter from Locke to Lady Guise, sent from Rotterdam and dated 21 June 1688 (new style). ${ }^{10}$ After that it quickly become quite common, being used three times in a letter to Lord Mordaunt written very soon after Locke's return to England in February 1689, and twice more in a letter sent to Jane Stringer in July. ${ }^{11}$ In letters sent in 1690 and 1691, than was used 12 times, then only once. ${ }^{12}$

The picture that emerges from the evidence presented here is that Locke changed with surprising rapidity from using then to using than in the second half of 1688, with only infrequent relics of the older usage observable in the years that followed. It would, perhaps, be unwise to assume that the transition was always as sharp as this, but it does seem safe to conclude that the change was made during his final year in the Netherlands.

\section{\$2. Two Ethical Writings}

The great majority of the works that Locke left in manuscript can be confidently dated either from their contents or because Locke himself supplied a date when he docketted them for filing. There are, however, a few exceptions, two of which will be examined here.

1. In the guard-book MS Locke c. 28 in the Bodleian Library there is a short ethical piece beginning 'Thus I thinke' which contains no indication whatever in the manuscript of when it was

${ }^{9}$ It is by no means unlikely that I have missed something, but if there are any occurrences of than they are certainly not common. Then as a conjunction is by contrast quite common: for examples in 1687-88, see The Correspondence of John Locke, ed. E. S. de Beer (Oxford, 1976-), iii. 239 (twice), 321 (twice), 322, 326, 429, 445, 446, 448, 455, 456; cited below as Correspondence.

${ }^{10}$ Correspondence, III, 470.

${ }^{11}$ Correspondence, III, 574, 575, 661.

${ }^{12}$ Correspondence, IV, 120, 140 [then], 137, 138, 139 (three times), 240, 274, 332, $333,335,340$. 
written. ${ }^{13}$ It was first printed by Lord King, who placed it in a section of 'Miscellaneous Papers', and did not hazard any date. ${ }^{14}$ H. R. Fox Bourne thought that it was probably written before 1667, and though Maurice Cranston did not propose a specific date, his treatment of it indicates that he supposed it to have been written during Locke's early years at Exeter House, i.e. in 1667 or soon afterwards. ${ }^{15}$ Mark Goldie very tentatively ascribed it to c.1686-8, and Paul Schuurman in his Digital Locke Project equally tentatively to $1692 .^{16}$

The investigations described in the previous section throw some further light on the matter. The word than does not occur in the manuscript, but then (used as a conjunction) does three times, once in the main text and twice in a deleted paragraph. The piece can therefore be assigned with some confidence to the period before 1689 .

2. Also in the same guard-book there is a short piece 'Morality' whose date is more controversial. ${ }^{17}$ It was first printed in 1974 by Thomas Sargentich, who did not suggest a specific date but remarked that 'since it is highly hedonistic, it was probably written relatively late in Locke's life'. ${ }^{18}$ Paul Schuurman held that it was 'possibly related to Molyneux's

${ }^{13}$ Bodl., MS Locke, c. 28, fos 143-4, 153-4. The manuscript consists of a quire of four leaves into the middle of which the manuscript of Of Ethick in General has been inserted, though whether by Locke himself or subsequently is not certain; the third and fourth leaves are blank, apart from Locke's endorsement 'Ethica' on fo. 154'; it is possible that this was added later, and Locke gave no date because he could not remember precisely when the piece had been written.

${ }^{14}$ The Life of John Locke (London, 1829), 304-5.

${ }^{15}$ H. R. F. Bourne, The Life of John Locke (2 vols., London, 1876), I, 164; Maurice Cranston, John Locke: A Biography (London, 1957), 123-4.

16 Locke: Political Essays, ed. Mark Goldie (Cambridge, 1997), 296; see http://www.digitallockeproject.n1/cgi/t/text/textidx?c=locke;sid=2a9abe8cd9e22eacc943 7e95e58d9114;tpl=texts-metadata.tpl;id=18 for Schuurman's ascription.

${ }^{17}$ Bodl., MS Locke, c. 28, fos 139-40.

18 'Locke and Ethical Theory: Two MS. Pieces', Locke Newsletter 5 (1974): 24-31, at 24 . 
insistence that Locke produce a demonstrated ethics', and suggested a date of $c .1692-c .1696 .{ }^{19}$ Other writers have, however, proposed a much earlier date. About half-way through the piece there is an account of how property rights arise: 'one man at his birth can have noe right to any thing in the world more then an other', with the consequence that 'men therefor must either enjoy all things in common or by compact determin their rights'. This is manifestly incompatible with the theory set out in the Two Treatises of Government in which property rights arise unilaterally by the mixing of labour, and it provides a very strong reason for supposing that 'Morality' had been written before this theory was devised. Patrick Kelly therefore proposed a date around 1677-8, and in this he has been followed by a succession of other writers. ${ }^{20}$

The passage from 'Morality' quoted in the previous paragraph contains the word then used as a conjunction, and the same word with this meaning appears on two further occasions, once in the main text and once in a passage that was subsequently deleted; than, by contrast, does not occur anywhere. Quite apart from the issues raised by the account of property-acquisition, this pattern of usage makes a date in the 1690s distinctly unlikely.

\section{§3. Two Treatises of Government}

Since the work of Peter Laslett in the 1950s and 1960s, it has been almost universally agreed that although the Two Treatises were published towards the end of 1689 , both parts were largely written during the last years of Charles II's reign, at some time during Locke's stay in England from 1679 to 1683, after which

\footnotetext{
${ }^{19} \mathrm{http} / /$ www.digitallockeproject.nl/cgi/t/text/textidx?c=locke; sid=246658fcaf6e9fdad4d3786d4734a4c2;tpl=texts-metadata.tpl;id=34

${ }^{20}$ Patrick Kelly, "“All things richly to enjoy": Economics and Politics in Locke's Two Treatises of Government', Political Studies 36 (1988): 273-93, at 281; Mark Goldie, Locke: Political Essays, 267; David Armitage, 'John Locke, Carolina, and the Two Treatises of Government', Political Theory 32 (2004): 602-27, at 617. John Marshall rather more cautiously suggested a date of 'probably... between 1676 and 1680': John Locke: Resistance, Religion and Responsibility (Cambridge, 1994), 193.
} 
the manuscript remained somewhere in England while Locke was in the Netherlands. Some changes are likely have been made in the months that preceded publication, but with the exception of the evidence provided by the existence of two states of the first edition, ${ }^{21}$ any conclusions about the stages of composition have to be drawn from the content of the text itself, and are therefore for the most part highly speculative. ${ }^{22}$

Any survey that draws its data from books printed in the early modern era faces an immediate problem: the spellings found these were determined ultimately by the compositor (or compositors), modifying - or alternatively leaving unchangedthe spellings found in the manuscript from which they were working. In respect of the choice between then and than, the first edition of the Essay concerning Human Understanding is consistently modern: then as a conjunction does not appear at all. The Two Treatises presents a more complex picture. In the First Treatise than occurs only 3 times, then 72; in the Second Treatise the proportions are approximately reversed, than occurring 124 times, then 12.

When the occurrences of then and than are broken down by chapter, the following picture emerges:

\begin{tabular}{|lll|}
\hline & then & than \\
\hline Preface & 0 & 3 \\
\hline $\begin{array}{l}\text { First Treatise } \\
\text { chapter 1 }\end{array}$ & 0 & \\
chapters 2-11 & 72 & $1^{23}$ \\
\hline
\end{tabular}

${ }^{21}$ First described in Peter Laslett, 'The 1690 Edition of Locke's Two Treatises of Government: Two States', Transactions of the Cambridge Bibliographical Society 1 (1952): 341-47. They are very important because they show that extensive revisions to the last part of chapter 3 of the Second Treatise were made while the work was being printed.

22 The one exception is the reference to Judge Jefferies in $\$ 129$ of the First Treatise, described by Laslett as 'the only statement which undoubtedly belongs after 1688', Two Treatises of Government (Cambridge, 1967), 48.

${ }^{23}$ Chapter 11, §119. 
Second Treatise

$\begin{array}{lll}\text { chapter } 1 & 1 & 0 \\ \text { chapter } 2 & 9^{24} & 0 \\ \text { chapter 3 } & 1 & 0 \\ \text { chapters 4-19 } & 1^{25} & 124\end{array}$

It is apparent from this that the spellings used in the first three chapters of the Second Treatise conform to those found in chapters 2-11 of the First Treatise, and diverge from those in the remainder of the Second Treatise.

One possible explanation for this is that (with exception of the first chapter) the First Treatise was only lightly revised, as were the first three chapters of the Second Treatise, but the reminder of the Second Treatise was so heavily reworked that all the occurrences of then present in the manuscript which Locke recovered after his return to England were changed to than. This would point to a far heavier revision than either Laslett or any of his critics have proposed, and is for that reason not a very attractive supposition. Fortunately something much more plausible is available.

In the article in which Laslett revealed the existence of the two states of the 1690 edition, he also mentioned that this edition appears to have been divided between 'two printers, or at least two compositors', ${ }^{26}$ one having set gatherings $\mathrm{B}-\mathrm{Q}$, containing the whole of the First Treatise and the beginning of the Second as far as the end of Chapter 3 ('Of the State of War'), and the other having set the remainder of the Second Treatise and also the prelims - the title-page, preface and table of contents which together comprise gathering A. Fredson Bowers concurred with Laslett's conclusion, and also observed that the measure (the width of a line of type) is approximately $1 \mathrm{~mm}$ narrower in the

${ }^{24}$ Two of these occur in a quotation from Hooker which has then in the edition (London, 1666) that Locke used.

${ }^{25}$ Chapter 19, §216.

${ }^{26}$ Laslett, 'The 1690 Edition of Locke's Two Treatises of Government', 345. 
part of the volume that was set by the second compositor. ${ }^{27}$

It can hardly be an accident that the point of division between the work of two compositors coincides with the change from then to than. The almost total prevalence of than in the Second Treatise from chapter 4 onwards is therefore merely a sign that the second compositor was now at work, ${ }^{28}$ and provides no evidence of what the readings had been in the manuscript from which he was working (almost certainly not Locke's autograph, but a fair copy made by someone else, probably Brounower who was routinely entrusted with such tasks).

Two parts of the volume where than was used exclusively remain to be considered: the Preface and the first chapter of the First Treatise. There is nothing remotely surprising about the presence of than in the Preface: the prelims were normally the last part of the book to be set, and in this case appear to have been set by compositor II. What is much more significant is the presence of than in $\S 1$ and $\S 2$ of the first chapter, which was certainly set by compositor I. It is not inconceivable that he began modernising the text and then gave up, but a more likely explanation is that Locke did indeed thoroughly revise the opening of his work, and that the presence of than in the printed text is an indication of this.

London

${ }^{27}$ Fredson Bowers, Johan Gerritsen and Peter Laslett, 'Further Observations on Locke's Two Treatises of Government', Transactions of the Cambridge Bibliographical Society 2 (1954): 63-87, at 64.

${ }^{28}$ The two compositors would almost certainly have been working simultaneously, providing material for two presses. Bowers held that compositor II started work on gathering $\mathrm{T}$, and only subsequently set gatherings $\mathrm{R}$ and $\mathrm{S}$, which had originally been assigned to compositor I ('Further Observations', 63-64); whether or not this is correct is (fortunately) not relevant here. 